\title{
Application Research on Role Assignment Method in Higher Vocational Accounting Teaching
}

\author{
Huihua Wang ${ }^{1}$, Guoping Luo ${ }^{1}$ \\ ${ }^{1}$ Jiangxi Institute of Economic Administrators, Nanchang, 330088, China
}

Keywords: Role Assignment. Higher Vocational Accounting Teaching. Scenario Simulation

\begin{abstract}
It has become a hot spot discussed by people in recent years to reform higher vocational teaching and improve teaching efficiency. This paper plans to discuss the application of role assignment in higher vocational accounting teaching. It analyzes the current situation and existing problems of higher vocational accounting teaching, and elaborates application of role assignment in higher vocational accounting teaching from accounting theory teaching and practical teaching.
\end{abstract}

\section{Definition of role assignment method}

Role assignment is actually a kind of scenario simulation. In the virtual scene, subjects are given certain character roles so that they will have a sense of being personally on the scene. They will try their best to imagine the mentality of virtual roles and solve problems in the most reasonable way. This method has rather strong property of participation, so if it can be applied into teaching process, students' positivity of participating in teaching activities will be fully aroused. Integrating learning with entertainment is able to give full play to students' positivity better than merely attending classes and taking notes. As for students who act as audiences all the way, scenario simulation will be far more vivid than teachers' teaching on stage so that their memory of learning contents is easier to be deepened. In the role assignment process, cooperation, exchanges and communication among roles are needed to increase their emotional contact and cultivate their social acceptability of communication, self-expression, mutual cognition, etc. Especially when role assignment is conducted in different groups, students' collective honor and team spirit can be cultivated better.

\section{Current situation of higher vocational accounting teaching}

Accounting is a discipline with strong technicality and applicability. Higher vocational teaching should train students' theoretical analysis ability, and also practice their actual operational ability and adaptive capacity in accounting environment. Only in this way can students meet the job requirements and get started to operation as soon as possible. However, current accounting teaching basically remains as traditional teaching mode. That is to say, teachers are still putting on "one-man show" and students are only listening with ears. It is one-way "spoon-feeding" teaching mode with its specific performance as follows:

Accounting teaching can be divided into classroom teaching and practical teaching from daily teaching links

Classroom teaching activities take teachers, who convey accounting knowledge to or impart accounting knowledge into students through classroom teaching, blackboard-writing and instructional media, as the main body. It purely emphasizes knowledge instruction and adopts "spoon-feeding" classroom teaching. Students merely obtain knowledge mechanically and passively. In the whole teaching process, teachers play a leading role at the dominating place, while students play an audience role at the passive place. Such kind of method makes theoretical teaching even more boring. As time passes, students will become tired of classes, ideal teaching efficiency can't be achieved, and the needs of higher vocational education talents can't be fulfilled. From practical teaching link, most colleges have built accounting practical training rooms in which students can use accounting knowledge they have learned to deal with accounting events and prepare accounting statement in simulative accounting environment. Even though it has achieved certain practical effects, 
there still exist some problems. Firstly, positions are independent with each other so that students can accomplish each step of accounting treatment all by themselves. But it doesn't take communication and coordination of positions into consideration. Secondly, the practical training rooms are usually small and poorly equipped with outdated practical training facilities. At last, the practical projects are basically confined to financial accounting without contact with advanced ERP software and electronic commerce system which are closely linked with accounting information system.

From the perspective of testing learning effects, teachers' method of testing students' theoretical learning effects still remains to be final examination under traditional accounting teaching mode

This method in fact can't achieve the expected goal. The reason is that higher vocational students nowadays have rather low consciousness of learning in their spare time. In order to deal with final examinations, a part of students will make efforts at the last moment by mechanically memorizing exam tips and the worse part of students will even cheat in the examinations. Even though the students, no matter the former or the latter, have passed the examinations, they don't really digest and absorb the professional knowledge. Therefore, it will cause consequence that students don't have correct understanding of their own ability and defects and it is not good for students to learn effectively in time. In practical training link, teachers ask students to hand in voucher, account book and statement as achievements. However, some students even though with relatively keen interest in practical training can't accomplish the tasks alone for the reasons that they don't study seriously and don't have enough ability to use theoretical knowledge. Consequently, plagiarism happens occasionally between students.

\section{Application of role assignment in higher vocational accounting teaching}

According to above status analysis on higher vocational accounting teaching, it is showed that higher vocational teaching reform represents the general trend. The key is how to guide students to be initiative rather than passive in learning process and improve their positivity. Adopting role assignment is good on basis of its present application effects. Its specific application is as follows:

\section{Application of role assignment method in accounting theoretical teaching}

In theoretical teaching, role assignment method uses virtual scene and role definition to make students try transpositonal consideration. Teaching in the past is a kind of rigid imparting. Teachers make every effort to analyze the theory, and students have to memorize mechanically and follow the patterns if they can't understand. Of course if the students can understand what teachers have taught, it is the best. In this way, teachers are so tired to teach over and over again and students may not accept. The consequence of memorizing mechanically is transient memory without application effects. If students are given a certain role to make them have a sense of being personally on the scene, they will be as responsible and profitable as a rational economic man who won't take a beating. Then some certain theories can make sense. Traditional teaching is simple one-way "spoon-feeding" method. Adopting role assignment method turns teaching from two parts into three parts, and the "virtual role" as bridge makes teaching and learning easier. 

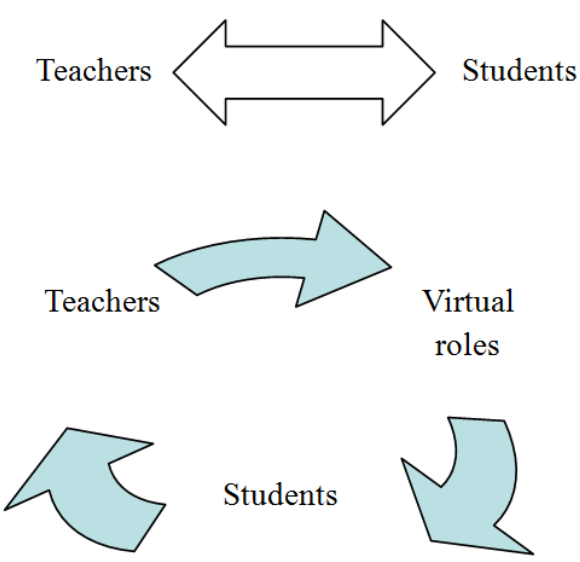

For example, when teaching the planned cost method of inventory pricing, "raw material" account is to check the planned cost and "material purchase" account is to check the actual cost. Their balance will be included in "material cost variance". In teaching process, teachers emphasize repeatedly that the amount of acceptance and storage in "raw material" is product of planned price and actual storage amount. But students can't understand anyway. At this moment, role assignment method can solve this problem very well. Teachers can give students the role of a warehouseman and then ask them, "If you are a warehouseman and the storage material now is lacked, should you put in storage the actual number or planned number?" They must answer with one voice, “Actual number". The way of role assignment is better than teachers' teaching formula and principle for no matter how many times, and the students' will never forget. For another example, when introducing bill process, teachers will draw the process chart and explain step by step. No matter how tireless the teachers are in elaborating process, students will mostly forget it after listening. If teachers set up a scene, give students roles as payee, payer, deposit banks of both sides, etc, and ask them to simulate the processing of drawing a bill, accepting and make collections, the classroom atmosphere can become active. In addition, it will increase students' learning initiative because they think it is fresh and funny, and finally achieves good teaching effects.

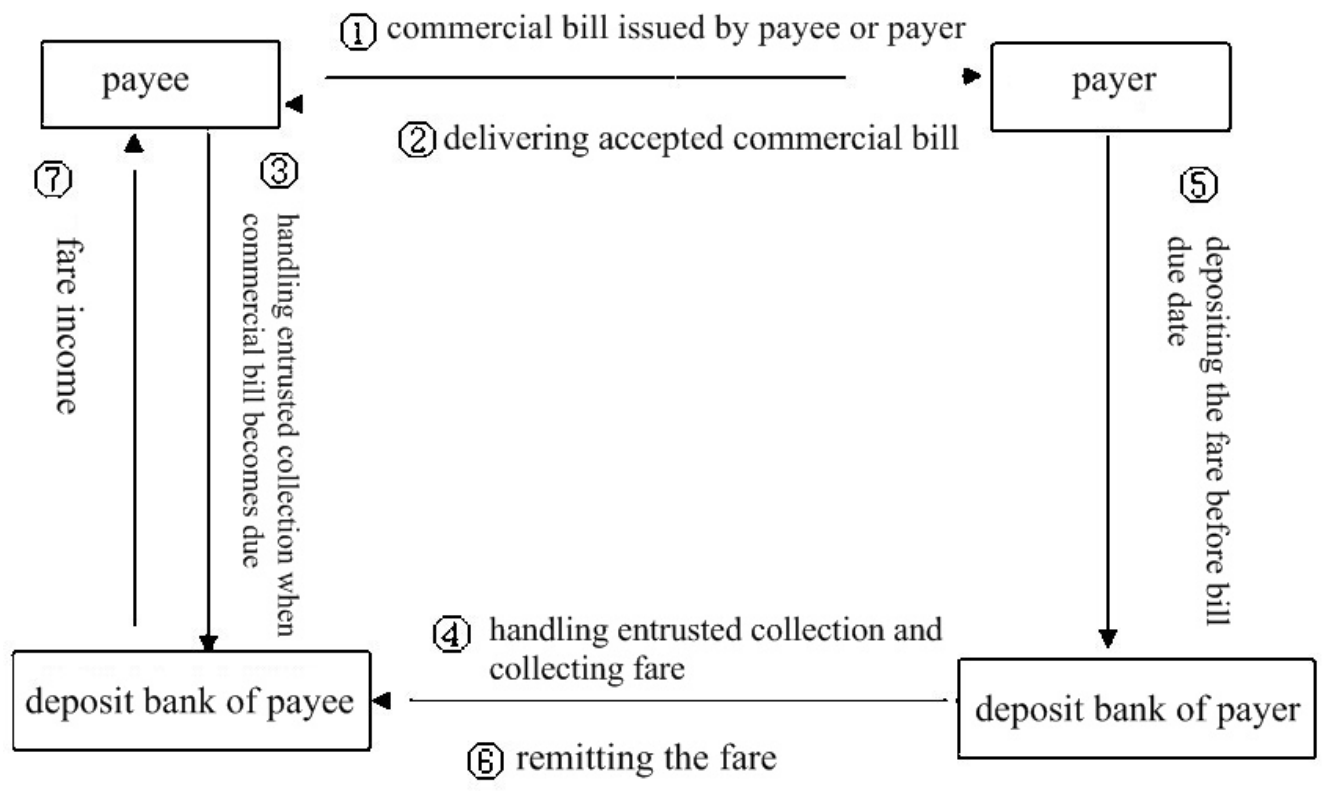

Accounting subject has so strong systematicness that the knowledge contents can be integrated naturally. Only by learning the previous contents well can students learn the following parts. They can also naturally use previous knowledge when learning the following parts. If we want to strengthen students' professional interest, we have to make every effort to build active classroom atmosphere. Simulated dialogue doesn’t merely belong to foreign language classes. Accounting 
courses can also realize professional dialogues through role assignment in order to make students find everything fresh and new, to achieve ideal teaching effects, and to digest all professional knowledge.

\section{Application of role assignment in accounting practical training}

Accounting practical training is another link of accounting teaching. It offers students more perceptual and intuitional understanding of all kinds of accounting information carriers (like voucher, account book and statement) through manual training. But if we only move these objects into practical training rooms and ask students to fill in one by one and to independently accomplish a complete set of business process, the effects are not so obvious and students will feel complex and tired. Applying role assignment method into this process will make teaching effects markedly different. We firstly get students to form groups of three and respectively give them roles as cashier, accountant and financial executive. Their respective responsibilities are assigned in accordance with real enterprises. Students as cashiers are responsible for advanced down payment and storage, filling in original voucher, issuing checks, clearing bank business, and the registering, settling accounts and checking of cash in banks journal. Students as accountants are responsible for filling in accounting voucher, checking in relevant account book, settling accounts and checking accounts. Students as financial executives should play the role of accounting department principal. They are responsible for re-checking accounting voucher, making categorized accounts summary, registering general ledger, making accounting statement and accounting information's arrangement and storage. After assignment, students will perform their own duties in accordance with their respective roles and know fairly well their working contents with obviously rising positivity. They will have deep understanding of each position and basic accounting process after one round.

Then we can carry out job rotation system after one round of practice, changing team members' roles and making them play different roles by turns. After several rounds, students will have more intuitive understanding of every position and more profound impression of work that should be accomplished in actual operation. Moreover, it also practices students' cooperative and communicative ability in practical work.

\section{Problems of applying role assignment method in higher vocational accounting teaching}

\section{Roles should be assigned according to circumstances}

The employment starting point of higher vocational accounting major students is relatively lower than students of other undergraduate colleges. They mostly obtain employment in middle and small-sized enterprises, so role assignment shouldn't completely accord with post setting in large-size enterprises. The financial regulations and job responsibilities of middle and small-sized enterprises should also be taken into consideration. In addition, there is hardly any enterprise which adopts only manual or computerized accounting. We should also keep pace with the times by integrating both methods when assigning roles in teaching.

\section{Being sure that students act as "leading role"}

Role assignment method is making students to "act”, breaking traditional teaching mode that teachers put on a "one-man show", and making students initiative. In the whole process, teachers can merely participate appropriately and shouldn't take on all things. They may demonstrate some typical business for students hand by hand after role assignment and then let students handle all by themselves. Students should be allowed to make mistakes. In the process of filling in voucher, registering account book and making accounting statement, students must make all kinds of mistakes in which they will get practice and grow up. Teachers only need to elaborate the key points, difficulties and representative mistakes, and remind them timely. It is real "letting it go" to make students find out problems, raise problems and solve problems. Finally students can be the real "leading role".

All in all, accounting teaching should accord with the principles of linking theory with practice and intuitive teaching. Considering different teaching contents, teachers should strengthen sense of reality and flexibility of teaching contents as much as possible, improve students' perceptual 
knowledge, imagery thinking and participation awareness, and enhancing accounting teaching effects.

\section{Acknowledgments}

This paper is the educational reform project named Application Research on Accounting Role Assignment Method in Accounting Comprehensive Training in Jiangxi Province. Project number: JXJG-12-91-2

\section{References}

[1] Luo Guoping, \& Yu Xiaofei: Application of accounting profession role assignment and transition in higher vocational practical teaching. Financial Community 2009 (12)

[2] Liu Yongze, Wu Dajun, Liu Shulian, \& Liu Yuanyuan: Application of modern teaching methods in accounting teaching. Journal of Dongbei University of Finance. 2004（6） 